\title{
Enzyme histochemical analysis on cryostat sections of human bone marrow
}

\author{
MARCO CHILOSI, ${ }^{*}$ GIOVANNI PIZZOLO,$\dagger$ GEORGE JANOSSY $\ddagger$ MARGARITA \\ BOFILL, $\ddagger$ LUCIANO FIORE-DONATI* \\ From the * Istituto di Anatomia e Istologia Patologica, the $\uparrow$ Sezione di Ematologia, Università di Padova, Sede di \\ Verona, Italy, and the $\ddagger$ Department of Immunology, Royal Free Hospital School of Medicine, London
}

SUMMARY A recently developed procedure, that has been shown to be suitable for detailed immunohistological analysis, has been used to prepare cryostat sections of bone marrow to investigate whether enzyme-histochemical techniques are also feasible on such material. A selected group of enzymes, some of which are inhibited or destroyed in paraffin- or plasticembedded samples, have been demonstrated. The morphological details obtained were satisfactory in the preparations. The enzymes were dipeptidyl(amino)peptidase IV (for T lymphocytes); tartrate-resistant acid phosphatase (for hairy cell leukaemia); acid phosphatase and non-specific esterase (for macrophages and monocytes); ATPase and 5'nucleotidase (for B lymphocytes); and peroxidase or chloroacetate esterase (for granulocytic cells). In these preparations strong enzyme activities were shown. In adjacent sections the immunological analysis of membrane markers could also be performed contributing to a comprehensive study of the normal and malignant bone marrow cells.

Both histochemical ${ }^{1-3}$ and immunological methods ${ }^{2}$ are routinely used for the analysis of bone marrow aspirates in leukaemias and lymphomas. Similar studies performed on bone marrow biopsies could potentially be more informative because in histological preparations the tissue organisation is maintained. It is nevertheless very difficult to reconcile the different technical requirements which are necessary for optimal morphological, histochemical and immunological analysis of tissue biopsies. Some excellent enzyme histochemical studies have been already performed on bone marrow using cryostat and paraffin sections of prefixed, edetic acid decalcified tissue blocks, ${ }^{4-6}$ or methacrylate-embedded samples without decalcification. ${ }^{78}$ Nevertheless under these conditions sensitive enzymes such as magnesium-dependent adenosine triphosphatase (ATPase), 5'nucleotidase (5'Nase) and dipeptidyl(amino)peptidase IV (DAPIV) are inhibited or destroyed. ${ }^{910}$

Intracytoplasmic immunoglobulins can be successfully demonstrated on paraffin and plastic sections of bone marrow using immunoperoxidase technique. ${ }^{71}$ Nevertheless consensus has been recently reached about the fact that the staining of $T$

Accepted for publication 13 April 1982 and B lymphoid cells with antisera to membrane? associated antigens is severely handicapped by fixation and/or embedding procedures. ${ }^{12} 13$

Recently an interesting new development has taken place in the immunological analysis of malignant non-Hodgkin's lymphomas. Some laboratories have emphasised that in properly processed frozen sections not only can excellent staining of membrane antigens be achieved but also the preservation of tissue morphology is acceptable. ${ }^{121415}$ In line with this new trend we have demonstrated that bone marrow trephine biopsies embedded in gum-sucrose can be frozen and conveniently cut in a cryostat with the preservation of tissue (including membrane) antigenicity and morphology. ${ }^{16}$

In this paper we demonstrate that cryostat sections obtained with the same method (or using N polyacrylamide gel as an alternative embedding medium) are also suitable for enzyme histochemistry. In addition to the enzymes which can be demonstrated in formalin-fixed paraffin- or plasticembedded material (see Methods) a number of other 0 enzymes could be detected in cryostat sections. These include $\mathrm{Mg}^{++}$-dependent ATPase, ${ }^{1718} \stackrel{\mathscr{C}}{-}$ 5 nucleotidase ${ }^{18}$ and dipeptidyl(amino)peptidase IV. 101920 


\section{Material and methods}

A few selected clinical cases have been studied as examples of the application of these methods.

\section{PATIENTS}

Three normal individuals (volunteers) and 12 patients were studied. The group of patients included eight cases of non-Hodgkin's lymphomas (NHL), one case of hairy cell leukaemia (HCL), two cases of B chronic lymphocytic leukaemia (B-CLL) and one case of $T$ type CLL (T-CLL). In six out of the eight NHL cases the diagnosis had been made on lymph node histology (three cases of centrocytic-centroblastic lymphoma, one case of Burkitt-like lymphoma, one case of immunoblastic lymphoma and one case of unclassified lymphoma). In these six patients the trephine biopsy was performed as a staging procedure. In three no involvement was seen; in the other three (one case of centrocytic-centroblastic, one Burkitt-like and one unclassified lymphoma) the B lymphoid infiltration of bone marrow was identified. In the remaining two of the eight NHL cases the diagnosis of malignant lymphoma was first reached on the basis of the analysis of bone marrow trephine biopsy. One of these cases had a lymphoplasmocytoid lymphoma, diagnosed by classical histology in paraffin-embedded decalcified sections. This diagnosis was confirmed by the immunohistological analysis of frozen sections which demonstrated uniform $\lambda^{+}, \mu^{+}$populations. In the other case some lymphoid nodules were detected in the paraffin embedded biopsy but the definite diagnosis of malignant $B$ cell proliferation was made by showing $\lambda^{+}$monoclonality of $\mathrm{B}$ cells on cryostat sections. In the three cases with CLL as well as in HCL the bone marrow involvement had been demonstrated by both histological and immunological analysis.

\section{PREPARATION OF SAMPLES}

Four $\mathrm{cm}$ long cores of bone marrow biopsies were obtained with an 11-gauge Jamshidi needle. Half of the sample was fixed in $10 \%$ formalin and embedded in paraffin after decalcification. ${ }^{21}$ The other half of the bone marrow core was submerged in gum-sucrose solution ( $1 \mathrm{~g}$ gum acacia $+30 \mathrm{~g}$ sucrose dissolved in $100 \mathrm{ml}$ distilled water) as previously described ${ }^{16}$ or embedded in polyacrylamide gel $(30 \%$ acrylamide, 1 $\mathrm{ml} ; 1 \%$ bis-acrylamide, $1 \mathrm{ml} ; 0 \cdot 5 \mathrm{M}$ Tris buffer $\mathrm{pH}$ $6.8,2.5 \mathrm{ml}$; distilled water, $5.33 \mathrm{ml} ; 10 \%$ ammonium persulphate $0.05 \mathrm{ml}$; TEMED $0.005 \mathrm{ml}$ ) and snapfrozen in liquid nitrogen. These frozen cores of bone marrow samples were stored at $-70^{\circ} \mathrm{C}$ until sectioning. In spite of the fact that no decalcification was performed no damage to the knife was evident when the sections (7-10 $\mu \mathrm{m}$ thickness) were cut in the cryostat. These sections were quickly dried on glass slides, fixed in neutral $10 \%$ calcium-formalin $\left(4^{\circ} \mathrm{C}, 5\right.$ min), washed in distilled water and air dried with a fan. This preparation was used for all enzymes except DAP-IV where cold chloroform-acetone mixture was used as a fixative ( $5 \mathrm{~min}$ ).

Reagents were from Sigma, St Louis, MO, with the exception of glycyl-prolyl-4-methoxy-betanaphthylamide purchased from BACHEM Feinchemikalien AG, Bubendorf/Schweiz.

The histochemical demonstration of the enzymes has been carried out as follows:

Non-specific esterase (NSE) with and without fluoride inhibition, using $\alpha$-naphthyl acetate dissolved in ethylene glycol monomethylether (EGMME) $(20 \mathrm{mg} /$ $0.5 \mathrm{ml}), 0.067 \mathrm{M}$ neutral phosphate buffer $(50 \mathrm{ml})$ and freshly prepared hexazonium pararosaniline (HPR) $(2 \mathrm{ml})$ as a coupler. Incubation time $15-30 \mathrm{~min}$, room temperature. ${ }^{22}$

Acid phosphatase $(A C P)$ with and without $\mathrm{L}+$ tartrate inhibition, using naphthol AS-BI phosphate as substrate ( $10 \mathrm{mg}$ dissolved in $0.5 \mathrm{ml}$ EGMME), $\mathrm{pH}$ 5 acetate buffer $(50 \mathrm{ml})$ and HPR $(2 \mathrm{ml})$ as coupler; incubation time 1 hour at $37^{\circ} \mathrm{C} .{ }^{2328}$

Peroxidase $(P X)$ using diaminobenzidine $(20 \mathrm{mg}$ dissolved in $0.5 \mathrm{ml}$ EGMME), ${ }^{2+}$ neutral Tris buffer $(50 \mathrm{ml})$ and one drop $30 \% \mathrm{H}_{2} \mathrm{O}_{2}$; incubation time 1 () min, room temperature. ${ }^{25}$

Chloroacetate esterase ( $C A E)$, using naphthol AS-D chloroacetate $(3 \mathrm{mg}$ dissolved in $0.3 \mathrm{ml}$ dimethylformamide) as substrate, neutral $0.067 M$ phosphate buffer $(10 \mathrm{ml})$ and fast blue $B(10 \mathrm{mg})$ as coupler; incubation time $15 \mathrm{~min}$, room temperature. ${ }^{26}$

Alkaline phosphatase $(A L P)$ using naphthol AS-BI phosphate ( $10 \mathrm{mg}$ dissolved in $0.5 \mathrm{ml}$ EGMME) as substrate, $0 \cdot 1 \mathrm{M}$ Tris buffer $\mathrm{pH} 9(50 \mathrm{ml})$ and hexazonium new fuchsin $(0.5 \mathrm{ml})$ as coupler; incubation time $30 \mathrm{~min}$, room temperature. ${ }^{27}$ ATPase and 5'nucleotidase using modified leadmethods; ${ }^{18}$ incubation time, one hour, $37^{\circ} \mathrm{C}$.

Dipeptidyl(amino)peptidase IV (DAP-IV), using glycyl-prolyl-4-methoxy-beta-naphthylamide $(2 \mathrm{mg}$ dissolved in $0.2 \mathrm{ml}$ dimethylformamide) as substrate, neutral $0.067 M$ phosphate buffer $(5 \mathrm{ml})$ and fast blue B as coupler $(5 \mathrm{mg})$; incubation time one hour, $37^{\circ} \mathrm{C} .{ }^{1020}$

After histochemical staining the sections were counterstained with haematoxylin when needed and mounted in glycerol-formalin (9:1).

Parallel sections have been fixed in ethanol and incubated for $30 \mathrm{~min}$ at $20^{\circ} \mathrm{C}$ with goat antibodies to human kappa and lambda light chain directly labelled with fluorescein isothiocyanate (FITC) and washed for a further $30 \mathrm{~min}$ prior to mounting in glycerolformalin. 


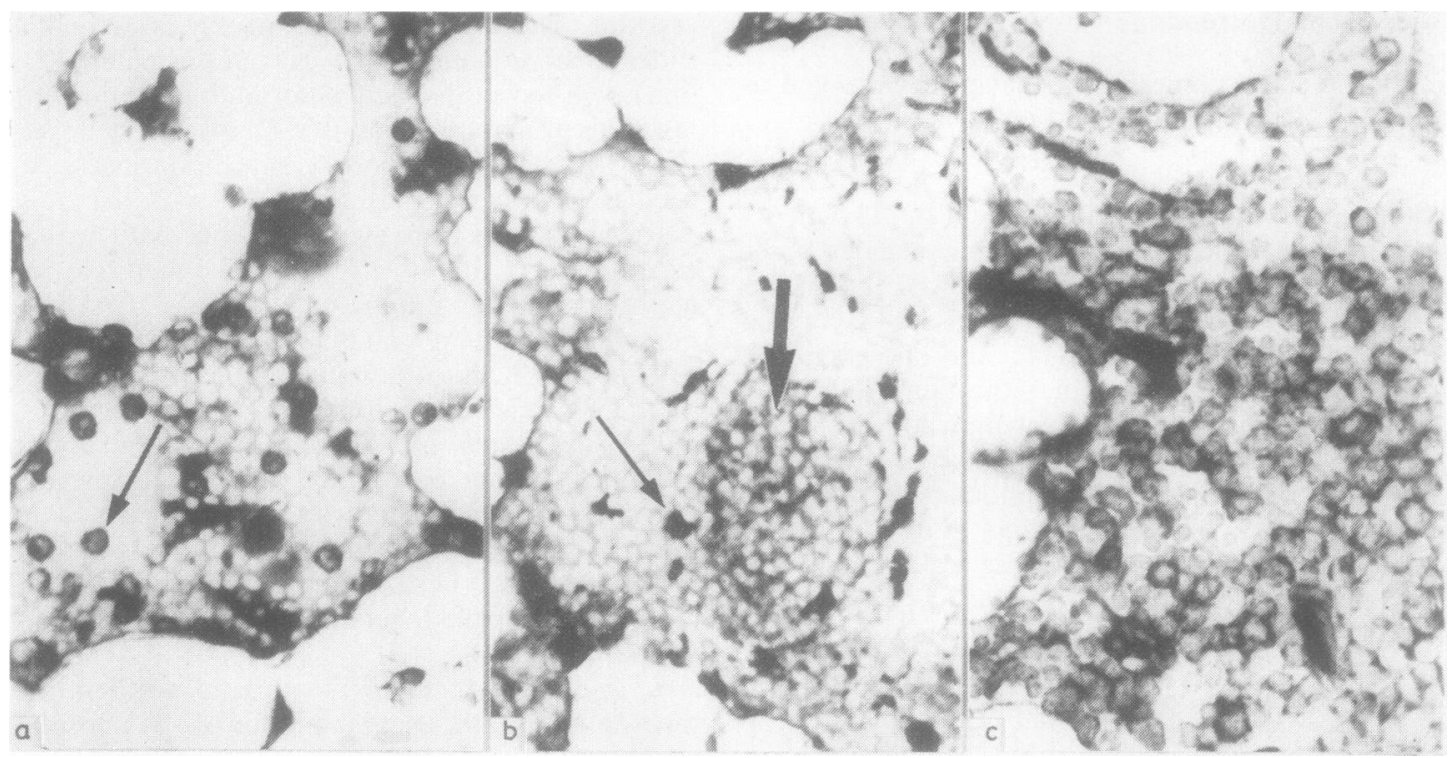

Fig. 1 Cryostat sections of normal bone marrow. In (a) and (b) non-specific esterase (NSE) staining is shown. In (b) the non-neoplastic lymphoid nodule is composed of a network of NSE positive cells (large arrow) amongst NSE negative or slightly positive lymphocytes. The processes of the NSE positive cells are similar to the network of follicular dendritic cells within the germinal centres of lymph node. Around the lymphoid nodule scattered strongly NSE reactive macrophages are also seen (small arrow). In the section adjacent to (b) the same lymphoid nodule has been stained for ATPase (c). The membranes of $B$ lymphocytes are ATPase positive. No nuclear counterstaining was used. (a) $\times 250$; (b) $\times 250$; (c) $\times 400$
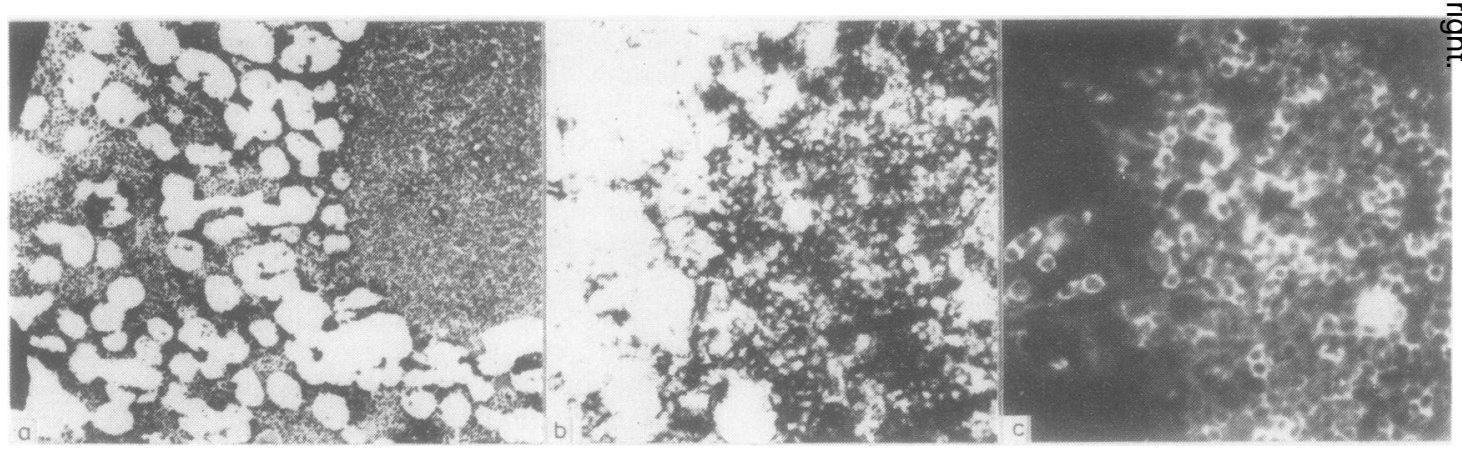

Fig. 2 Cryostat sections of bone marrow with B-cell lymphoma $\left(\mathrm{IgM}^{+}\right.$, lambda $\mathrm{a}^{+}$monoclonal population $) .(\mathrm{a})=$ haematoxylin and eosin stain ( $\times 70)$; in (b) lymphoid cells on a serial section to (a) show ATPase positive membrane staining $(\times 250)$, no nuclear counterstaining; in (c) the same neoplastic nodule, on a serial section, immunostained for antilambda light chain (direct immunofluorescence method-FITC), photographed on a fluorescence microscope with filters for FITC. $V$ irtually all $B$ cells are stained. Similar staining was seen with anti IgM ( $\mu$ specific) but staining with anti kappa light chain was negative (not shown). $(\times 400)$

\section{Results}

PREPARATION OF BONE MARROW BIOPSIES As previously reported ${ }^{16}$ gum sucrose embedding is important for obtaining good sections of frozen bone marrow biopsies. This is a thick fluid which can nevertheless easily penetrate into the bone marrow cavities and thus gives a compact homogeneous plasticity to the frozen samples. This is necessary for

even cutting. The morphological quality of these sections is obviously inferior to those obtained from paraffin- or plastic-embedded tissues, but the details obtained in the haematoxylin-stained sections of the frozen material are surprisingly rich and adequate for certain diagnostic purposes (Figs 1 and 2). Using polyacrylamide gel as an alternative embedding medium thinner sections can be obtained improving the histochemical and immunohistological analysis. 
ANALYSIS OF NORMAL AND NON-INVOLVED BONE MARROW SAMPLES

In these six specimens all enzymes studied were successfully demonstrated. Peroxidase (PX) and chloroacetate esterase (CAE) distinguished granulocytic cells from erythroid, megakaryocytic and monocytic cells which were mainly unreactive. Alkaline phosphatase (ALP) was positive in capillary endothelium and in fibroblast-like cells. Nonspecific esterase (NSE) was a suitable marker for megakaryocytes, monocytes and resident macrophages. These macrophages could be distinguished from monocytes by their irregular shape and more intense positivity (Fig 1). Fluoride abolished NSE reactivity in monocytes as well as in a large proportion of macrophages.

Lymphoid nodules were observed in two normal bone marrow samples. The lymphocytes in these nodules appeared to show slight reactivity for NSE. These lymphocytes formed contacts with processes of dendritic cells which had higher NSE activity. These dendritic cells had similar shapes and reactivity to the follicular dendritic cells seen in germinal centres of lymph nodes ${ }^{22}$ (Fig 1).

A somewhat similar histochemical pattern was observed with acid phosphatase (ACP) except that the expression of ACP activity was stronger in the disseminated bone marrow macrophages than in dendritic type cells or monocytes. L+tartrate completely inhibited the ACP reactivity in all of these cell-types except in a few macrophages and, when evident, some osteoclasts.

ATPase and 5'nucleotidase activities were mainly observed in the blood vessel walls and in the lymphocyte membranes within the lymphoid nodules (Fig 1c).

DAP-IV activity was confined to a few scattered $T$ lymphocytes and to endothelial-like structures corresponding to the sinuses.

\section{ANALYSIS OF MALIGNANT LYMPHOID \\ INFILTRATION}

The lymphoid cells had virtually no PX and CAE activity while the residual granulopoietic tissues were strongly positive for these enzymes. Thus the malignant infiltrations which obliterated the normal bone marrow structure could be clearly visualised (Figs 3 and 4).

Both the diffuse and nodular infiltrations were obvious. The NSE was unreaccive or only slightly positive with lymphoma cells but a variable number of strongly NSE positive scattered "reactive" macrophages were seen amongst these neoplastic cells.

Certain enzymes positively identified the neoplastic lymphoid populations (Table). ATPase

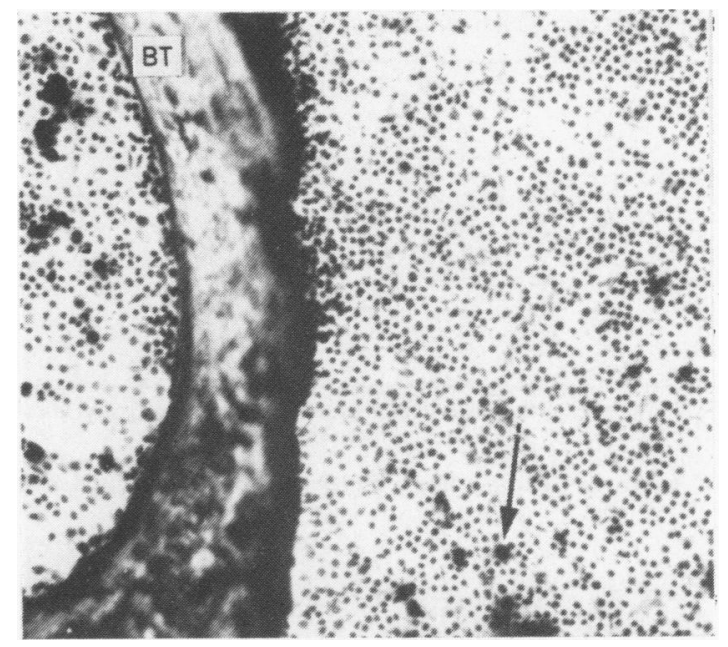

Fig. 3 Cryostat section of bone marrow involved by lymphoplasmocytoid lymphoma $(\times 100)$. The peroxidase reaction clearly indicates the areas with few residual granulocytic cells (arrow). The neoplastic cells diffusely obliterate the bone marrow structure and appear to be peroxidase negative. $B T=$ bone trabecule. The section is counterstained with haematoxylin.

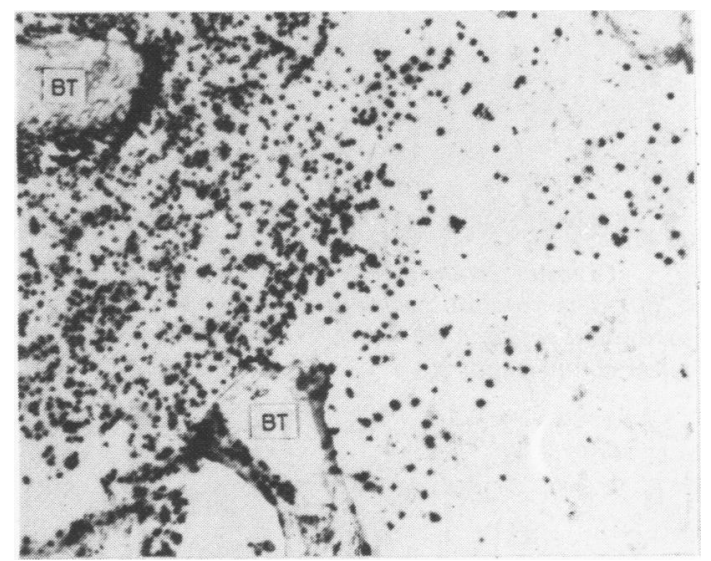

Fig. 4 Cryostat section of bone marrow involved by Burkitt-like lymphoma $(\times 70)$. Chloroacetate esterase staining shows the area of residual granulocytic cells; the negative area on the right is mainly formed by neoplastic lymphoid cells. No nuclear counterstaining.

could be demonstrated on the malignant $B$ lymphocytes in two cases of centroblastic-centrocytic lymphomas, one case of lymphoplasmocytoid lymphoma and in the two cases of B-CLL. This feature of the malignant $B$ cells paralleled a similar ATPase reactivity on normal bone marrow nodules (Fig 1). The single case of T-CLL (and similarly normal $T$ lymphocytes) were however ATPasenegative. In contrast DAP-IV was negative not only 
The selectivity of enzyme activities demonstrated in biopsies of frozen bone marrow*

\begin{tabular}{|c|c|c|c|c|c|c|c|c|}
\hline & $T$ cells & $T-C L L$ & B cells & $\begin{array}{l}\text { B-type } \\
\text { NHL }\end{array}$ & $\begin{array}{l}\text { Hairy cell } \\
\text { cell } \\
\text { leukaemia }\end{array}$ & $\begin{array}{l}\text { Granulopoietic } \\
\text { cells }\end{array}$ & Macrophages & $\begin{array}{l}\text { Dendritic } \\
\text { ret cells of } \\
\text { lymph nodules }\end{array}$ \\
\hline $\begin{array}{l}\text { †DAP-IV }{ }^{101920} \\
\text { ATPase }^{1820} \\
\text { 5 Nase } \\
\text { ACP }^{18031} \\
\text { TRAP }^{28} \\
\text { CAE }^{2326} \\
\text { PX }^{23} \\
\text { NSE }^{222}\end{array}$ & $\begin{array}{l}+ \\
- \\
- \\
\S \\
- \\
- \\
-\end{array}$ & $\begin{array}{l}+\ddagger \\
- \\
- \\
- \\
- \\
- \\
- \\
\S\end{array}$ & $\begin{array}{l}- \\
+ \\
+ \\
- \\
- \\
- \\
- \\
\pm\end{array}$ & $\begin{array}{l}- \\
+1- \\
- \\
- \\
- \\
- \\
- \\
-1 \pm\end{array}$ & $\begin{array}{l}- \\
- \\
- \\
+ \\
+ \\
- \\
- \\
-\end{array}$ & $\begin{array}{l}- \\
- \\
- \\
+1- \\
- \\
+1++ \\
+1++ \\
+1-\end{array}$ & $\begin{array}{l}- \\
- \\
- \\
++ \\
- \\
- \\
+ \\
++\end{array}$ & $\begin{array}{l}- \\
- \\
+1- \\
+1- \\
- \\
- \\
- \\
+\end{array}$ \\
\hline
\end{tabular}

*Alkaline phosphatase was demonstrated on blood vessels and fibroblast-like cells.

†DAP-IV activity was also present on sinus lining cells.

$\ddagger$ One case of our series.

$\S$ Demonstrable as a "dot-like" positivity only on formalin fixed samples.

+ /-Variable.

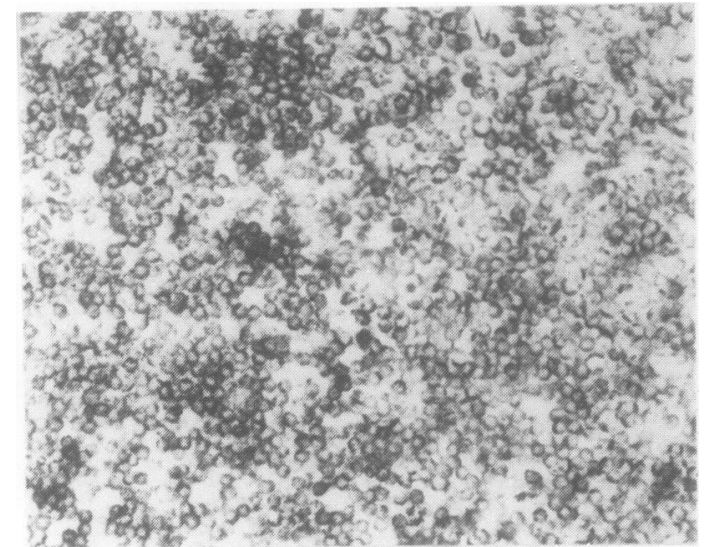

Fig. 5 Cryostat section of bone marrow involved by T-CLL ( $\times 250)$. The neoplastic cells diffusely obliterate the bone marrow and appear to be strongly reactive for DAP-IV. No nuclear counterstaining.

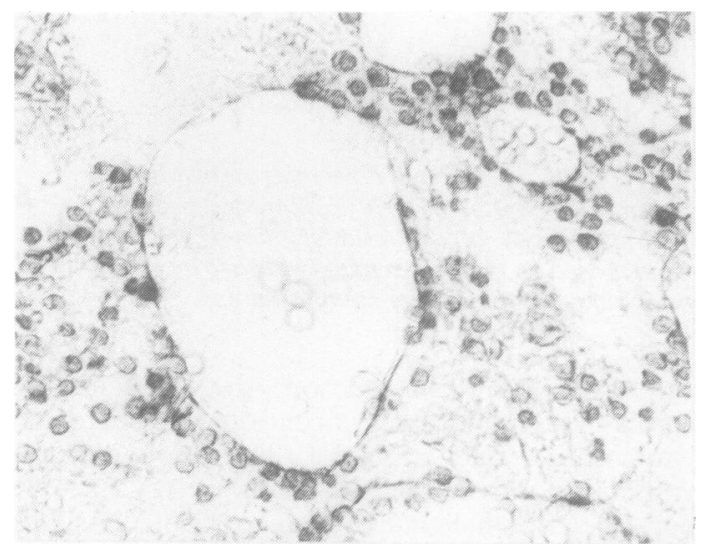

Fig. 6 Bone marrow involved by hairy cell leukaemia; cryostat section $(\times 300)$. The neoplastic cells exhibit variable reactivity for $L+$ tartrate resistant acid phosphatase (TRAP) and replace the normal marrow. in residual normal bone marrow cells but also in all cases of $\mathrm{B}$ lymphoid malignancies. The one case of T-CLL studied was, however, strongly DAP-IV positive (Fig 5). 5 'nucleotidase was negative or highly depressed in the neoplastic cells of all cases.

Finally PX, CAE, NSE, ATPase and 5 'nucleotidase enzymes were all negative in the case of hairy cell leukaemia (HCL). Many HCL cells expressed ACP variable activity resisitant to tartrate inhibition (TRAP) confirming the diagnostico specificity of this enzyme on HCL using cryostaro sections (Fig 6). ${ }^{28}$

\section{Discussion}

Our observations and the findings by other groups are briefly summarised in the Table. The enzymes chloroacetate esterase (CAE), non-specific esterase (NSE), peroxidase (PX) and both alkaline and acid phosphatase (ALP, ACP) can be demonstrated in fixed paraffin and methacrylate-embedded samples. ${ }^{89}$ Our results confirm previous observations about the distribution of these enzymes in the various normal and infiltrating cell types of the bone marrow. These enzymes together with the periodic acid-Schiff reaction are also used for the routine histochemical analysis of bone marrow smears. ${ }^{1-3}$

The important point in the Table is that this range of "classical enzymes" as well as the more sensitive DAP-IV, ATPase and 5'nucleotidase can be detected in sections of frozen bone marrow biopsies with surprising ease and sensitivity. DAP-IV, ATPase and 5 'nucleotidase are normally inhibited or destroyed by fixation and embedding procedures. Further details about the comparative sensitivity of histochemical methods applied on formalin-fixed paraffinembedded and frozen tissue blocks have been described elsewhere. ${ }^{9}$

Amongst the panel of reagents shown in the Table the individual enzymes have distinct "roles" to play. 
CAE and PX or ACP and NSE characterise granulopoietic cells and subpopulations of macrophages, respectively. These enzymes always clearly demonstrate the extent to which the bone marrow is replaced by neoplastic lymphoid cells. The other three enzymes, DAP-IV, ATPase and TRAP can positively identify whether these infiltrating cells are of $T, B$ or hairy cell origin.

We feel that the relatively simple and economical methods shown here are valuable in routine histopathological analysis of bone marrow disorders for two main reasons. Firstly, as we have showed previously ${ }^{16}$ similarly processed bone marrow samples can be stained with various antisera for the detection of both membrane and cytoplasmic antigens. The uniform "monoclonal" light chain expression-that is, predominantly kappa or lambda. of the malignant $\mathrm{B}$ lymphoid population can be established. The new range of murine monoclonal antibodies for lymphoid subsets have also been applied with success in these adjacent sections. ${ }^{16}$ The histochemical methods are standard procedures and the monoclonal antibodies are becoming commercially available. It will, therefore, be possible. with the application of the described methods, to compare routinely the histochemical findings with the immunological phenotypes on normal and malignant cells. Secondly, parts of the bone marrow cores should be always preserved for routine histology. A further improvement is to cut the bone marrow cores longitudinally and process one part with plastic embedding (for optimal morphology) and the other part with gum sucrose embedding and freezing (for histochemistry and immunology), as has been suggested by Bartl and his colleagues. ${ }^{-9}$ In this way adjacent areas of optimally processed tissues can be analysed by complementary techniques.

Finally, we would like to call attention to the observation that $5^{\circ}$ nucleotidase is negative or weakly expressed in neoplastic B lymphocytes when compared to the strong expression of normal B cells in the follicle lymphocyte corona. ${ }^{1718.3131}$ This observation can already help to establish, together with the immunological analysis, whether the small focal nodules in the bone marrow of patients with lymphoma are aggregates of normal B cells or represent predominantly malignant populations. Nevertheless, the explanation of this phenomenon is unclear. It may represent malignancy associated changes in the expression of a membrane-linked enzyme, or may simply reflect that the 5 'nucleotidase negative $B$ lymphomas derive from a B cell subset which is different from the corona $B$ cell. As the analysis of subset heterogeneity (within normal B cell populations) by recently developed monoclonal antibodies has already been started ${ }^{32} 34$ it will soon be feasible to investigate this question further.

'Bennet JM, Reed CE. Acute leukemia cytochemical profile: diagnostic and clinical implications. Blood cells 1975;1:101-13.

Catovsky D. The leukaemic cell. Edinburgh. ChurchillLivingstone, 1981

"Hayhoe FGJ, Quaglino D. Haematological cytochemistry. Edinburgh: Churchill- Livingstone, 1980.

+ Grouls V. Diagnosis of hairy-cell leukemia by tartrate resistant acid phosphatase activity in paraffin-embedded tissue sections. $J$ Clin Pathol 1980;33:552-4.

${ }^{5}$ Mori M. Ito M. Fukui S. Decalcification for histochemical demonstration of hydrolytic and oxidative enzymes. Histochem J 1965;5:185-91.

- Yam LT. LiCY. Wolfe HJ, Moy PN. Histochemical study of acute leukemia. Arch Pathol 1974;97:129-35.

Beckstead JH, Bainton DF. Enzyme histochemistry on bone marrow biopsies: reactions useful in the differential diagnosis of leukemia and lymphoma applied to 2-micron plastic sections. Blood 198();55:386-94.

* Westen H. Mück KF. Post L. Enzyme histochemistry on bone marrow sections after embedding in methacrylate at low temperature. Histochemistry 1981;70:95-105

"Chilosi M. Pizzolo G. Menestrina F. Iannucci A. Bonetti F. FioreDonati L. Enzyme histochemistry on normal and pathologic paraffin-embedded lymphoid tissues. Am J Clin Pathol $1981 ; 76: 729-36$.

"" Chilosi M. Pizzolo G. Menestrina F. Iannucci A. Bonetti F. FioreDonati L. Dipeptidyl(amino)peptidase IV (DAP IV) histochemistry on normal and pathologic lymphoid tissues. $\mathrm{Am}$ J Clin Pathol 1982:77:714-9.

"Pinkus GS. Seid JW. Specific identification of intracellular immunoglobulin in paraffin sections of multiple myeloma and macroglobulinemia using an immunoperoxidase technique. $A m$ J Pathol 1977:87:47-58.

:2 Taylor CR. Immunohistologic studies of lymphoma. Past, present and future. J Histochem Cytochem 198();28:777-87.

"Warnke R. Pederson M, Williams C, Levy R. A study of lymphoproliferative diseases comparing immunofluorescence with immunochemistry. Am J Pathol 1978:70:867-75.

it Janossy G. Thomas JA. Pizzolo G. Granger SM. McLaughlin J. Habeshaw JA. Stansfeld AG. Sloane J. Immunohistological diagnosis of lymphoproliferative diseases by selected combinations of antisera and monoclonal antibodies. $\mathrm{BrJ}$ Cancer 198():42:22+42

's Stein H. Bonk A. Tolsksdorf G. Lennert K. Rodt H. Gerdes J. Immunohistological analysis of the organization of normal lymphoid tissue and non-Hodgkin lymphomas. $J$ Histochem (itochem 198();28:746-60).

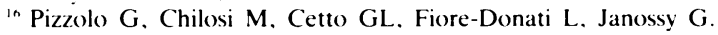
Immuno-histological analysis of bone marrow involvement in lymphoproliferative disorders. Br J Haematol 1982:50:95-10().

Harigaya K. Mikata A. Suzuki H. Ohishi T. Kageyama K. Minato K. Shimoyama M. $\mathrm{Mg}^{+{ }^{+}}$-dependent adenosine triphosphatase as an enzyme histochemical marker for the lymphomas of $B$ cell origin. Am J Pathol 1979;97:359-80.

'^ Müller-Hermelink HK. Characterization of the B-cell and T-cell regions of human lymphatic tissue through enzyme histochemical demonstration of ATPase and $5^{\circ}$-Nucleotidase activities. Virchows Arch [Cell Pathol] 1974;16:371-8.

"Feller AC. Parwaresch MR. Specificity and polymorphism of diaminopeptidase IV in normal and neoplastic $\mathrm{T} \mu$ lymphocytes. $J$ Cancer Res Clin Oncol 1981:101:59-63.

"Lojda Z. Studies on glycyl-proline naphthylamidase. I. Lymphocytes. Histochemistry 1977:54:299-309.

$\because$ Rywlin AM. Histopathology of the bone marrow. Boston: Little Brown and Co, 1976. 
22 Chilosi M, Menestrina F, Pizzolo G, Maconi A, Iannucci A, Bonetti F, Fiore-Donati L. Fluoride resistant $\alpha$-naphthyl acetate esterase and combined enzyme histochemistry in the study of normal and pathologic lymphoid tissues. Basic Appl Histochem 1981;25:39-50.

${ }^{23}$ Barka T, Anderson PJ. Histochemical methods for acid phosphatase using hexazonium pararosanilin as coupler. $J$ Histochem Cytochem 1962;10:741-53.

${ }^{24}$ Chilosi M, Bonetti F, Iannucci A. Carcinogenic 3,3'diaminobenzidine (letter). Am J Clin Pathol 1981;75:638.

is Graham RC, Karnovsky MJ. The early stages of absorption of injected horse radish peroxidase in the proximal tubules of mouse kidney: ultrastructural cytochemistry by a new technique. J Histochem Cytochem 1966;14:291-302.

it Moloney WC, McPherson K. Fliegelman L. Esterase activity in leukocytes demonstrated by the use of naphthol AS-D chloroacetate substrate. J Histochem Cytochem 1960;8:200-7.

"7 Li CY, Yam LT, Crosby WH. Histochemical characterization of cellular and structural elements of the human spleen. $J$ Histochem Cytochem 1972;20:1049-58.

¿x Yam LT, Li CY, Lam KW. Tartrate-resistant acid phosphatase isoenzyme in the reticulum cells of leukemic reticuloendotheliosis. N Engl J Med 1971;284:357-60.

:4 Bartl R. Burkhardt R, Vondracek H, Sommerfeld W, Hagemeister E. Rationelle Beckenkamm-biopsie. Längsteilung der
Proben zur Anwendung von mehreren Präparationsverfahren ohne Materialverlust. Klin Wochenschr 1978;56:545.

") Lopes J, Zucker-Franklin D, Silber R. Heterogeneity of 5 -nucleotidase activity in lymphocytes in chronic lymphocytic leukemia. J Clin Invest 1973;52:1297-300.

"Quagliata F. Faig D. Couklyn M. Silber R. Studies on the lymphocyte 5 nucleotidase in chronic lymphocytic leukaemia, infectious mononucleosis normal subpopulations, and phytohemagglutinin stimulated cells. Cancer Res 1974;34:3197202.

32 Janossy G, Tidman N, Papageorgiou ES, Kung PC, Goldstein G. Distribution of $T$ lymphocyte subsets in the human bone marrow and thymus: an analysis with monoclonal antibodies. J Immunol 1981;126:1608-13.

${ }^{33}$ Caligaris-Cappio F, Gobbi M, Bofill M, Janossy G. Infrequent normal B lymphocytes express features of B-chronic lymphocytic leukemia. J Exp Med 1982;155:623-8.

${ }^{44}$ Nadler LM. Stashenko P, Hardy R, van Agthoven A, Terhorst C. Schlossman SF. Characterization of a human B cell-specific antigen (B2) distinct from Br J Immunol 1981;126: 1941-7.

Requests for reprints to: Dr M Chilosi, Istituto di Anatomia e Istologia Patologica, Policlinico di Borgo Roma, Verona 37100 , Italy. 